\title{
The Perils and Challenges of Advancing Economic Governance Reform in Indonesia: An Endeavor by the Technocrats in the New Order Era
}

\author{
Vishnu Juwono \\ Faculty of Administrative Science \\ Universitas Indonesia \\ vjuwono@ui.ac.id
}

\begin{abstract}
Soekarno government in the late 1960's, the army chief General Suharto emerged as a new leader with the primary task to repair Indonesia's economic growth and restore the international community's confidence in Indonesia's economy. To carry out this tremendous challenge, Suharto appointed a group of talented economist from the University of Indonesia who mostly were graduated from the United States best known as the Technocrats. The Technocrats were able to assist Suharto in restoring and even delivering an unprecedented economic growth of more than $5 \%$ with full support from the international community during the late 1960s to the early 1990s. However, in the next stage, the Technocrats had to face even more challenges as they confronted vested interest groups when they tried to push for substantial economic governance reform, like the so called 'financial generals', conglomerates and nationalist bureaucrats.
\end{abstract}

This article will provide an analysis on the political aspects of the Technocrats embarking on this economic governance reform and identifying the extent of the progress of this reform. This article reveals how the Technocrats were eventually overwhelmed by their political adversary, thus was only able to deliver limited economic governance reform. This article utilizes primary sources including diplomatic correspondence, memos, reports from the United Kingdom (UK) Foreign Commonwealth Office and the Australia Department of Foreign Affairs as well as Indonesian and international mass media articles. To complement the documents, interviews with more than 30 relevant resource persons who mainly served or were indirectly involved in Suharto's government.

Keywords-economic governance reform, the Technocrats, the New Order Era, Soeharto

\section{INTRODUCTION}

In power for more than three decades, Indonesia's second president Suharto developed Indonesia's political governance structure from a slightly competitive one into an authoritarian form. For this he needed vast economic and financial resources to funnel into his political and military activities in the form of foreign investment and international loans from donors usually channeled through the Technocrats.

The Technocrats consisted of economists at the University of Indonesia, led by Widjojo Nitisastro, with Ali Wardhana, and Emil Salim among them, a group , which was also known as the 'Berkeley Mafia,' since some of them had been educated at the University of California, Berkeley ('The Berkeley Mafia Meets the Military,'16 May 1980). The Technocrats initially became acquainted with Suharto in the Army Staff and Command School in Bandung, SESKOAD from 1962-1964 (Acrobatics Technocrats Star in Indonesian Balancing Act,' 16 May 1980).

This article will discuss the political dynamics regarding how the Technocrats faced tremendous challenges in pushing for governance reform in the economic sector during the New Order era, especially from their political rivals - the financial generals, the politico bureaucrats, the Chinese conglomerates, Suharto's family and the engineering group led by the Minister of Research and Technology B.J. Habibie. This article will also outline how Suharto consolidated the authoritarian structure that led him to the pinnacle of power in the late 1980s - early 1990s by further dismantling the checkand-balance system, but this at the same time put him in a vulnerable political position as evident in his downfall in May 1998.

The article aims at contributing to the existing Indonesia academic literature on contemporary political history, focusing on governance reform in the economic sector executed by the Technocrats. Most of the literature on the role of the technocrat in New Order Era New Order era has focused on either in the fraction period in that era (Bresnan 1993, Winters 1996, Djiwandono 2005) or a memoir or compilation of 
speeches that rely on the technocrat perspective in that era that usually avoids critical assessment on Suharto economic policy (Prawiro 1999; Nitisastro 2011; Sumarlin 2013; Wardhana 2015). Most of the existing academic literature that is critical toward Soeharto has situated the Technocrats in a political struggle against other powerful groups that had an influence on economic policy, such as the conglomerates or nationalist bureaucrat (Bresnan 1993; Winters 1996; Schwarz 2009; Wanandi 2012). Despite mentioning the Technocrats' efforts in reform, the main focus of analysis of these literatures dominated by Suharto's political role in that period.

Therefore, the contribution of this article is to provide a comprehensive picture and rigorous analysis that centers on the Technocrats' efforts in pushing governance reform in the economic sector amid strong resistance from their political rivals or vested interests in Indonesia such as Suharto's crony conglomerates.

\section{THEORETICAL REVIEW}

This article will apply political pluralism as its analytical framework. The political pluralism approaches which advocate the need for high quality democracy became internationally recognized by the American leading political scientist Robert Dahl (1968; 1998). According to Dahl, democracy can only flourish in a market-oriented economy. However, as the economy grows, a tension arises between democracy and the market economy. Also, according to Dahl, the market system becomes an impediment to achieving high quality democracy because it also creates inequality within political resources, including wealth, income, organization, information, education and knowledge (Dahl 1998).

The application of the political pluralism approach in the case of Indonesia is quite similar to Dahl's approach. The seminal work of Feith (1962), analyzing the political rivalry between the administrator group led by Hatta and the solidarity-maker group led by Sukarno in the parliamentary democracy era from the 1940s to the 1950s, also mentions the number of economic governance reforms pushed by the administrator group.

During Suharto's New Order era, a number of leading Indonesian experts combined political pluralism theory with patrimonial state theory. They observed that, despite the prowess of Indonesia's military rule, which in the last ten years became Suharto's personalization rule, there was still space for political rivalry. The competition between elite groups under the authoritarian rule of Suharto did not necessarily have to be about wealth or resource accumulation, but also about fundamental policy - in this case reform.

This kind of analysis was applied by a number of leading scholars and analysts of Indonesian studies. However, the studies either only covered a fraction of the New Order era period like Bresnan (1993), Soesastro (1989), Liddle (1999)
Winters (1996) or only mostly emphasized economic policy without factoring political contexts like Hill (2000) and Booth (1998). Therefore, this article aims at complementing the existing academic literature by both taking into account political dynamics that the Technocrats had to navigate as well as the whole period of the New Order era.

\section{RESEARCH METHODOLOGY}

This article is based on empirical research undertaken through a wide variety of primary sources, which is mainly based upon non-Indonesian archives. The rarely-used primary sources are from the UK, and Australian embassies in Jakarta, available at the British National Archives and the Australian National Archives, while the recently published US Embassy cable was accessed via the Wikileaks website. The Indonesian newspapers were accessed from the Indonesia National Archives in Jakarta as well as the library of the Institute of Southeast Asia Studies (ISEAS) in Singapore, like Pedoman, Indonesia Raya, Kompas, Sinar Harapan, Tempo and Suara Pembaruan. Data was obtained from the ISEAS library, the Far Eastern Economic Review and Asiaweek. The Indonesian laws and regulations are also one of the primary sources that were obtained from the official Indonesian Cabinet Secretary's office (http://sipuu.setkab.go.id/).

The documents from archives, government institutions and NGOs were further supplemented by newspapers in the New Order Era period. From the New Order era until the postSuharto period, the focus was on national newspapers and current affairs magazines, such as Kompas, and Tempo. This research also used articles from leading Indonesian news websites, like detik.com, Tempo.co and vivanews.com.

Written historical records and documents were further supplemented by interviews with relevant resource persons. More than 80 interviews with high-ranking government officials were conducted including state officials, MPs, Indonesian and foreign businessmen, Indonesian and international Non Governmental Organizations (NGO) activists, Indonesian and foreign journalists, as well as academic researchers specializing in Indonesian politics.

The interviewees involved in my research (2011-2014) were in Jakarta, Yogyakarta, Singapore, Canberra, Sydney, Melbourne and Singapore. These interviews served the purpose of adding details to the written documentation and exploring the motivation behind the key decisions, especially those made by the Technocrats during Suharto's government.

\section{DISCUSSION}

\section{1) Governance as Development Issues}

The concept of governance reform as development is widely used not just in academic discourse, but also as public 
discourse, therefore it provokes a contentious debate on this issue. The sectoral governance reform concept that focuses on economic issues, which is the focus of this article, for instance, in the 1990s was about dismantling state intervention in economic affairs through liberalization, among others, in trade, finance or capital flow, as pushed by the International Financial Organizations, such as the World Bank and IMF, in less developed and developing countries. This policy was known as 'structural adjustment' or the 'Washington consensus' (Williamson 1994).

Meanwhile in the 'post-Washington consensus', in which the World Bank departed from their previous stance for small governments, in the late 1990 s to early 2000s, they advocated the need to strengthen the government's capacity to formulate and implement policy in the context of managing the country's economic resources for development (World Bank 1992). This definition, that emphasizes the empowerment of the government to implement policy, was also advocated by leading academics, like Pierre and Peters (2000).

In my view, governance reform can be defined as a conscious and concerted effort by reformist elements within the state, in this case the Technocrats, which sometimes forges an alliance with civil society and the media, to build democratic governance in the economic sector to ensure that public goods are distributed indiscriminately among the citizens. In terms of the time frame, the governance reform was seen as an effort to enact policies that have long-term implications, with the ultimate goal to distribute economic resources equally to reduce inequality between the rich and the poor. Therefore, the analysis in this article is to identify whether the Technocrats were able to carry out an economic governance reform, and how far they were able to push the reform in the New Order era.

\section{2) The Early Rivalry between Financial Generals and the Technocrats}

Since Indonesia's independence, the military has been involved in business and expanded its involvement during 1957. That was when the government declared martial law as the military was taking over most of the foreign companies which at the time were under the Dutch.

According to Crouch (1978), from the outset of the New Order era, the army saw that the expansion of their commercial activities was vital in supporting their role as the custodians of Indonesia's political stability, but also as an opportunity for the officers to accumulate tremendous wealth.

The prime example of military involvement in business during early period of the New Order era was their leadership role in the state oil company, PERTAMINA, and National Logistic Agency (BULOG) (Human Right Watch 2006). The establishment of PERTAMINA began in 1957 when the Indonesian army took over an unused oil field in North
Sumatra, with capital support from Japanese companies. After 1966, PERMINA was taken over by two other companies and renamed PERTAMINA led by army general Ibnu Sutowo (Article 2, Government Regulation 27, 1968, on the establishment of the state oil company PERTAMINA).

Between1969-1975, the government revenue from oil increased significantly from Rp. 66.5 billion to $\mathrm{Rp}$. 957.2 billion (Robison 1986, 152). Therefore, PERTAMINA was capitalizing on this windfall profit and its business expanded. Ibnu Sutowo's took on the role as the President's political financier, dispensing patronage through 'non-budgetary' financing to their allies in the military, government officials, businessmen, and state projects, like hospitals or Suharto's office's Bina Graha (US Embassy in Jakarta 1976).

As Suharto came to power in 1967-1968, the Technocrats were entrusted with tackling the formidable challenge of saving Indonesia's economy from the brink of collapse as inflation had reached 1000 percent a year and the government had amassed more than US\$2 billion in foreign debts (Prof. Subroto, personal communication, November 25, 2013).

Nevertheless, the Technocrats, led by Coordinating Minister for Economic Affairs Widjojo, had little choice but to turn to the international community in 1967-1968. They patched up Indonesia's relationship with multilateral donors agencies, like the World Bank and the International Monetary Fund (IMF) and with the industrialized countries, led by the U.S (Ambassador Phillips 1976).

However, the western donor countries, realized that the Technocrats were politically vulnerable and lacked a sufficient social base. Therefore, the US Embassy tried to help by informing the army leaders that Indonesia would not receive any aid unless it was approved by the Technocrats (Bradley 2008, 219).

The Technocrats succeeded in stabilizing Indonesia's economy within a couple of years by reducing inflation quickly and restoring their foreign creditors' trust (Prof Emil Salim, personal communication, December 23, 2013). This was demonstrated by the vast amounts of Indonesian foreign debt that was being rescheduled with generous terms of payment in 1967-1970 ("Widjojo Puts Case for Cooperation," 1976).

The implementation of the Five Year Development Plan was a success as in 1973 economic growth reached over 7\%, the investment rate increased by more than $15 \%$ and exports also increased substantially by $50 \%$ ('Dilemma of Repelita II,'1973). With the Technocrats' growing stature, they became the formidable foes of Ibnu Sutowo's PERTAMINA.

The Technocrats felt that their authority and effectiveness in coordinating Indonesia's economic policy were hampered by PERTAMINA's autonomy capital mobilization, because 
Sutowo had been very close to Suharto as fellow army officers (Ramadhan KH 2008).

Suharto was conscious of the two-track system in the New Order economy governance structure and tried to put Suharto above the fray should a conflict arise. However, the Technocrats were wary about the potential debt problem caused by PERTAMINA for international donors and creditors (The Australia Embassy in Jakarta 1972).

The concern of the Technocrats was vindicated when PERTAMINA's short-term debt increased almost tenfold from 1973 to 1975 , from US\$140 million to US\$1,000 million, that almost made the country bankrupt, with a total debt of around US10.5 billion ('A \$10- Billion Lesson,'1976).

As a result, the technocrat-led government reacted quickly by guaranteeing all of PERTAMINA's foreign loans, supervising the firm's management and establishing several commissions to investigate the scale of the PERTAMINA debt problem (Her Majesty's Ambassador to Jakarta 1975). Sutowo was eventually dismissed in March 1976 (The US Embassy in Jakarta 1976).

Another form of military involvement in the state enterprises was exemplified by BULOG which enjoyed a monopoly over the distribution and price determination of basic commodities, like rice, sugar and flour. Originally, BULOG's mission was to provide rice for civil servants and military officers, but in 1970 this was expanded to maintaining price stability for essential commodities through a policy of purchasing, importing, marketing and pricing.

However, following the leadership of army general Tirtosudiro from 1967-1973, an unpleasant legacy was left, as BULOG was plagued by a number of corruption cases (The US Embassy Jakarta 1972). The anti-corruption commission IV, led by former Prime Minister Wilopo, published a critical report, outlining, the potential deficit in BULOG's budget that had accumulated from 1968-1970 of around Rp. 44 billion ('Batasi Kegiatan BULOG dan Bubarkan BULOG,' 1970). Nonetheless, despite systematic corruption, even the Technocrats were unable to contain BULOG's influence.

When the rice price again rose at the end of 1972 due to insufficient stock, Suharto took decisive action by dismissing Tirtosudiro as head of BULOG and 'transferring' him to become the Indonesian Ambassador to West Germany in 1973. There were other generals involved in business; they were known as the 'financial generals' like Soedjono Humardani who became acquainted with Suharto when he commanded the army in Central Java (Malley 1991). Soedjono was also director of Tri Usaha Bhakti, the holding company of the military business comprising more than 30 institutions, with an estimated value of Rp.9 billion ('Bintang-Bintang di Gelanggang Dagang', 1973).
It was evident, from the various business-related schemes run by the Financial Generals that their main responsibility was to ensure a steady flow of funds into the army's coffers without causing economic disruption, contrary to Sutowo and Tirtosudiro's cases. As long as it was not disproportionate, they were permitted to reap part of the proceeds as a reward for their own efforts (Crouch 1976).

In the end, Suharto had only empowered the Technocrats vis $a$ vis the financial generals when crisis threatened the state economy, as in the case of PERTAMINA and BULOG, but never allowed them to take full control of economic policy in order to maintain the balance of power.

\section{3) The Rivalry between the Conglomerates and the Technocrats}

Suharto needed significant financial and economic resources to finance his political and military operations, which had formerly been provided by the financial generals in the late 1980s. There were several schemes intended to mobilize funding from conglomerates or his wealthy relatives. The conglomerates were asked to support Suharto's presidential assistance scheme, also known as Bantuan Presiden (Banpres) that was accumulated through the cloves monopoly granted to his brother, Probosutedjo, and his close business associate, Liem Sioe Liong. Suharto managed to collect Rp. 256 billion. The interest from this was at his disposal to undertake various social initiatives on his behalf $(\mathrm{G}$ Dwipayana and Ramadhan KH 1988, 292).

Another major avenue for mobilizing this off-budget funding from conglomerates was the charitable foundations, also known as yayasan. There were various methods available for accumulating funding for the yayasan from conglomerates; for instance, the foundations owned shares in companies that were majority-owned by the conglomerates, like textile factories, and flour mills. The most political of these foundations was Yayasan Dakab, which was established in 1985. At its peak, Dakab managed to accumulate assets worth US\$43 billion in 1985 (Abdulgani-Knapp 2007, 262). Other foundations followed suit, with Yayasan Damandiri accumulating approximately US\$23 billion for, Yayasan Gotong RoyonUS\$65 billion $g$ and Yayasan Dharmais Rp.474 billion.

The economic measures by the Technocrats had little effect on the monopolies owned by the conglomerates and Suharto's family businesses. However, when the Technocrats announced that 165 monopolies such as import quotas or other forms of tariffs were to be eliminated, they were only worth of US\$300-400 million per year or 3-4\% of Indonesia's total non-oil imports in 1985. Meanwhile, the import monopolies which still existed, like steel, plastic, and cotton, had an estimated value of US\$1.5 billion ("All in the Family: Indonesian Decrees Help Suharto's Friends and Relatives Prosper,'1986). Nonetheless, once the Technocrats had 
convinced Suharto of the importance of economic governance reform policies, the president could thwart any opposition to the policy (Basri and Hill 2004, 649).

The political motivation for the liberalization policy induced by the Technocrats was in some cases intended to challenge the monopoly of the Indonesian Chinese conglomerates. However, these conglomerates were in the best position to exploit the limitations of the liberalization policies (Booth 1998, 322).

As evident in 1988, the top 300 businesses, which were mainly Indonesian Chinese, had a combined sales turnover of Rp.70 trillion in 1989-1990. The largest conglomerate, the Salim Group, was owned by one of Suharto's associates, Liem Sioe Liong. In 1996, the Salim group's total sales were estimated to be around Rp.53 trillion, which was more than double that of the Astra Group and Sinar Mas.

Nevertheless, the inability of the Technocrats to push for substantial economic governance reform showed that Suharto ensured that the economic governance reform would not disrupt the economic governance structure that he created as the main source of patronage underpinned by his business cronies and families.

The resentment toward the growing business influence of the Indonesian Chinese conglomerates during the New Order era was pertinent during 1970s -1990 s. This resentment was especially felt among the indigenous business, political and bureaucrats' elites. Therefore, Suharto's government felt the need to accommodate this indigenous elite group, to contain their grievances.

There were several measures taken by the government to empower indigenous businesses to address this public discontent. One of them was the issuance of government Decree No 14/ 1979 that stipulated the need to advance indigenous businesses through government projects, with an estimated value of around Rp.50 million (Presidential Decision Decree 14, 1979 on the Execution of the State Budget). This protection policy, was expanded a year after the issue of Presidential Decree No. 10, 1980, which set up a team led by Suharto's trusted aides from the State Secretary Office (SEKNEG) to oversee the procurement of goods and services.

The so-called 'Team 10' was led by the influential State Secretary Sudharmono (Presidential Decision Decree 10, 1980, on the Team to Supervise Goods and Services Procurement for the Government). From the outset, the setting up of Team 10 coincided with the second oil boom, and its mission was to spend the $\$ 1.4$ billion oil boom windfall profit in the early 1980s (Kartasasmita 2013, 53). The Technocrats had a politically savvy adversary inside the government, reflected in Team 10.
During the eight years of its tenure, Team 10 channeled around Rp. 52 trillion (\$60billion) worth of government procurements to indigenous businesses (Winters 1996, 201). Therefore, the indigenous businesses capitalized on the window of opportunity provided by Team 10 including Fadel Muhammad who supplied fire hydrants; Aburizal Bakrie who provided pipes for construction work (Kartasasmita 2013, 53).

These indigenous businessmen were usually grouped into a number of business associations like HIPMI (The Association of Young Indonesian Businessmen), or KADIN (Indonesian Chambers of Commerce and Industry). Usually, they used these business associations as pressure groups to advance their collective business interests (Rosser 2002, 35).

\section{4) The Demise of the Technocrats}

The Technocrats had enjoyed almost unparalleled clout in shaping the economy policy terms since the early New Order era until the late 1980s. At the apex of their 20 years of influence, the Technocrats dominated the economic ministerial cabinet portfolio, like trade, industry and finance. However, the Technocrats' influence steadily declined since the late 1980s, starting with the retirement of Widjojo, and the Minister of Technology Habibie's political ascendancy.

This was due to a combination of factors which increased Suharto's self confidence as he practically did not have any credible political rivals, and so would be less dependent on the Technocrats but, more importantly, Habibie was able to convince Suharto that technology-led development was the way forward, and to allocate substantial economic resources as well as institutional facilities to help establish a long-term technological industry (Amir 2007, 94).

Habibie was the State Minister of Technology for 20 years, making him the longest-serving minister under Suharto. He also chaired the Agency of Strategic Industries (BPIS) which was a holding company of state-owned strategic industries, including transportation, defense equipment and weaponry. It is no wonder he was dubbed 'Super Minister' ('Sederet Jabatan', 10 October 1992).

The demise of the Technocrats' influence accelerated when Habibie became involved in politics in the early 1990s by joining the ruling party, Golkar, and later he was promoted to become the daily coordinator of the Golkar advisory board. Habibie, with Suharto's blessing, expanded his political reach by appealing to the Islamic urban group and becoming the chair of the Indonesian Muslim Intellectual Association (ICMI) (Asshidiqie 2002). The combination of political prowess through both Golkar and ICMI, and also Suharto's support for Habibie's technological development vision, proved a major set-back for the Technocrats.

Another challenging situation the Technocrats faced was the tremendous task of enforcing regulatory reforms in the face of the strong opposition from the conglomerates and 
Suharto's families. This vested interest managed to acquire loans especially from the state banks through back-channels with generous terms and violating the financial regulations by channeling disproportionally to their own business group. Consequently, when these businesses defaulted, several major banks collapsed, as shown by the spectacular fall of Bank Summa in 1992 (Robison and Rowser 1998, 1599).

To make matters worse, President Suharto was not shy about intervening with the Technocrats to advance his family's business interests. BI governor Soedrajad Djiwandono recalls vividly how Suharto intervened personally on Tommy's behalf to acquire a US\$1.3 billion loan from the Central Bank to finance his national car project (Prof. Soedarajad Djiwandono, personal communication, January 29, 2014).

During the peak of the financial crisis in 1997 - 1998, the Technocrats made a last attempt to push for fundamental governance reform, especially in the economic sector. Widjojo and Wardhana who were called by Soeharto to lead a negotiation effort with international donors led by the International Monetary Fund (IMF) during crisis, saw a rare opportunity for comprehensive reform by using the condition to get crucial financial and development assistance in exchange.

Evidently, IMF's supported Widjojo and the NGOs' reform agenda by accommodating their proposal in the first Letter of Intent (LOI) by the Indonesian government in October 1997 that outlined the government's intention for structural reform.

In the first LOI, the government promised to dissolve the monopoly over the import of wheat, flour, soya beans and garlic held by Suharto's family or cronies (Letter of Intent (LOI) Indonesia government to Managing Director of the International Monetary Fund (IMF), 1997). The LOI also contained a plan to postpone around 150 big government projects in an effort to reduce state expenditures so it could reduce the state budget deficit to $1 \%$.

However, the economic governance reform by the Technocrats was challenged by Suharto's family and cronies. When due to their unsustainable debts caused by the rupiah depreciation in November 1997, the Governor of the Central bank closed 16 insolvent banks, including some owned by Suharto's relatives who protested the decision ('Suharto Son Alleges Indonesian Official Tried to Sully Family by Closing Banks,'1997).

The government's efforts to restore market trust after closing the 16 banks failed. It was clear that Suharto never intended to implement the reform program endorsed by the IMF. In the end, Suharto was forced to resign in May 1998 after continuous pressure both from the Indonesian elites and the street demonstrations led by the students as well as the show of no confidence from most of his ministers.

\section{CONCLUSION}

The Technocrats with their limited authority were able to leverage economic governance reform particularly in the first two decades of the Suharto era. The peak of their influence, in my view, was when Widjojo and Wardhana held various economic portfolio ministerial positions together. They managed to convince Suharto of the merit of the technocratic approach to the economy policy that not only restored the economic morass under Sukarno in the late 1960s, but also witnessed remarkable economic growth exceeding $5 \%$, that brought Indonesia from a poor, low income to a low middle income country before the economic crisis of 1998. However, due to their lack of political acumen and being heavily dependent on Suharto in providing political cover to carry out a bold reform, their influence receded as soon as Suharto decided in the early 1990s that the economic governance reform did not match his political agenda that could be best served by his business cronies and other similar political groups like that were led by Minister Habibie. Thus overall, the Technocrats in my view were only able to bring about significant governance reform in the areas under their authority, such as trade, investment and financial sectors. Unfortunately, overall Suharto's economic patronage remained largely intact, breeding and sustaining corruption that continues even until today. Therefore, in the effort to curb or contain corruption, governance reform that was pushed by the Technocrats had only a negligible impact.

\section{ACKNOWLEDGEMENT}

The research for this paper particularly that conducted in London and Canberra was funded by the Jardine Foundation, Hong Kong, during author's $\mathrm{PhD}$ research at the London School of Economics (LSE), the United Kingdom. The earlier version of this paper was part of author's LSE dissertation in 2016 entitled 'Berantas Korupsi: A Political History of Governance Reform and Anti-Corruption Initiatives in Indonesia 1945-2014.'This paper also accommodated some constructive comments from discussants when it was presented in International Association of Schools and Institutes of Administration (IASA) Conference 2015, on 6 10 July 2015 in Paris, France.

\section{REFERENCES}

[1] Amir, Sulfikar (2007). 'Symbolic Power in a Technocratic Regime: The Reign of B.J. Habibie in New Order Indonesia', Sojourn: Journal of Social Issues in Southeast Asia, Vol. 22, No. 1, p. 94.

[2] Asshidiqie, Jimly (2002). Bang Imad: Pemikiran dan Dakwahnya. Jakarta: PT. Gema Insani Press.

[3] Australia Embassy (1972). From the Australian Embassy in Jakarta to Department of Foreign Affairs Australia, 9 March 1972, savingram no 16, File 3034/2/9/1, Indonesia: Corruption, the National Archives of Australia, Canberra. 
Beclouded: Proposals for Action at IGGI,' Lot File 76D446, Box 12, National Archives, the National Security Archives, the George Washington University, Retrieved on 15 November 2014 from http://www2.gwu.edu/ nsarchiv/NSAEBB/NSAEBB242/19721214.pdf, p. 6.

[5] Bresnan, John (1993). Managing Indonesia: the Modern Political Economy, New York: Columbia University Press

[6] Booth, Anne (1998). The Indonesian Economy in the Nineteenth and Twentieth Centuries: A History of Missed Opportunities, London: St. Martin Press.

[7] Crouch, Harold (1976). 'Generals and Business in Indonesia', Pacific Affairs, Vol. 48, No. 4, winter, 1975-1976, p. 524

[8] Crouch, Harold (1978). The Army and Politics in Indonesia, Ithaca: Cornell University Press.

[9] Dahl, Robert A. (1968). 'Pluralist Democracy in the United States'. Chicago: Rand McNally and Company.

[10] Dahl, Robert (1998). On Democracy, New Haven: Yale University Press.

[11] Dwipayana, G and Ramadhan KH (1988). Suharto: Pikiran, Ucapan dan Tindakan Saya, Jakarta: PT Citra Lamtoro Gung Persada, p. 292.

[12] Feith, Herbert (1962). The Decline of Constitutional Democracy in Indonesia. Ithaca: Cornell University Press.

[13] Hill, Hal (2000). The Indonesian Economy, Cambridge: Cambridge University Press.

[14] Kartasasmita, Ginandjar (2013). Managing Indonesia's Transformation: an Oral History, Singapore: World Scientific.

[15] Human Right Watch (2006). Too High a Price: The Human Rights Cost of Indonesian Military Activities, Vol. 18, No 50.

[16] Malley, Michael Sean (1991).'Sujono Humardani dan Orde Baru [Sujono Humardani and New Order', Prisma, Special Edition 20 years (1971-1991), 1991. p. 108.

[17] Phillips (1967). Ambassador Phillips to Secretary of FCO Brown, Letter (confidential), 'the State of Indonesia Economy,' 13 January 1967, no. 2E, FO 480/ 19, Further Correspondence Respecting Indonesia: January - December 1967, the UK Foreign and Commonwealth Office (FCO), Public Record Office (PRO), London, p. 8.

[18] Ramadhan KH (2008), Ibnu Sutowo: Saatnya Saya untuk Bicara!, Jakarta: National Press Club Indonesia.

[19] Rosser, Andrew(2002). The Politics of Economic Liberalization in Indonesia, Surrey: Curzon.

[20] Simpson, Bradley (2008). Economists with Gun: Authoritarian Development and U.S.-US-Indonesia relations in 1960-1968, California: Stanford University Press.

[21] Soesastro, Hadi (1989). 'The Political Economy of Deregulation in Indonesia,' Asia Survey, Vol. 29, No. 9, September 1989.

[22] The US Embassy Jakarta (1972, December 14). U.S. Embassy Jakarta to the Secretary of State, Telegram (confidential), 'Indonesia Miracle

[23] The US Embassy in Jakarta (1976, March 11). From the US Embassy in Jakarta to the US Secretary of State, cable (confidential), 'Dismissal of PERTAMINA Director Ibnu Sutowo,' p.3., Wikileaks, retrieved on 19 November 2014 from https://wikileaks.org/plusd/cables/1976JAKART03480 b.html

[24] The World Bank (1992). Governance and Development, Washington, D.C.: World Bank.

[25] The World Bank (2002). Reforming Public Institutions and Strengthening Governance: A World Bank Strategy. Washington, D.C.: World Bank.

[26] Pierre, J. and G. Peters (2000). Governance, Politics and the State, New York: Palgrave.

[27] Williamson, John (1994). The Political Economy of Policy Reform. Washington, D.C.: Institute for International Economics.

[28] Winters, Jeffrey (1996). Powers in Motion: Capital Mobility and the Indonesian State, Ithaca: Cornell University Press.

[29] 'Batasi Kegiatan BULOG dan Bubarkan BULOG (1970, July 22), 'Sinar Harapan, p. 3.

[30] 'Bintang-Bintang di Gelanggang Dagang' (1973, February 3), Tempo.

[31] 'Dillema of Repelita II (1973, October 29),' Far Eastern Economic Review, p. 50.

[32] 'A \$10- Billion Lesson' (1976), Asiaweek, no. 34, p. 15.

[33] 'Widjojo Puts Case for Cooperation,'(1976, October 8) Far Eastern Economic Review, p. 60.

[34] 'The Berkeley Mafia Meets the Military,' (1980, May 16) Far Eastern Economic Review, p. 49.

[35] 'Acrobatics Technocrats Star in Indonesian Balancing Act,' (1980, May 16) Far Eastern Economic Review, p. 45.

[36] 'All in the Family: Indonesian Decrees Help Suharto's Friends and Relatives Prosper,' (1986, November 24), Asia Wall Street Journal, p. 1.

[37] 'Sederet Jabatan'(1992, October 10), Tempo Magazine.

[38] 'Suharto Son Alleges Indonesian Official Tried to Sully Family by Closing Banks,'(1997, November 5), the Wall Street Journal.

\section{SHORT BIOGRAPHY}

Vishnu Juwono is a lecturer in public administration and researcher in the Collaborative Governance and Dynamic Public Services (CG-DPS) research cluster at the Faculty of Administrative Science, Universitas Indonesia. 